\title{
An Analytical Reading of Gloriana: a Ceremonial Opera of the Twentieth Century
}

\author{
Mai, Chih-Yuan \\ School of Foreign Languages \\ San-Ming University \\ Fujian, China \\ 18259762632@qq.com
}

\begin{abstract}
Gloriana, an opera based on the life of Queen Elizabeth I was Benjamin Britten and William Plomer's attempt to construct a national myth for a new era. The work is dedicated for the coronation of Queen Elizabeth II. Opera, as being a ritualistic art form, has played a crucial role in the series of coronation ceremonies in 1953. With the secularisation of the Western societies, civil rituals have gradually replaced religious ceremonies to be the binding force of a nation. Gloriana represents a form of civil ritual in a secularised society. However, by employing Queen Elizabeth I's controversial love affair with the Earl of Essex in her twilight years as the backdrop of the piece, the librettist and the composer have not only muffled the focus of the work but also creates several dramatic problems. The paper intends to explore the libre tto of Gloriana as a piece of theatrical writing; elaborates the ceremonial elements in the opera, analyses its dramatic purposes and finally discusses the opus' weaknesses which prevent the opera becoming one of the of operatic canon of the twentieth-century.
\end{abstract}

Keywords-Civil ritual, English libretti, Mythic narrative, Masque

\section{INTRODUCTION}

Gloriana, an English opera by Benjamin Britten and William Plomer, received its premier at the Royal Opera House, London as a part of the celebrations for Queen Elizabeth II's coronation [1]. This historical opus features Queen Elizabeth I as its central character. In the opera, in order to achieve the country's ultimate stability and benefit, the queen decides to sacrifice her private life and symbolically marries to her country. Britten and Plomer's opera clearly intends to actively participate in constructing a national myth and further suggests the coming the second Elizabethan era [2].

Set during the final years of Elizabeth I's reign, Britten and Plomer open their three act opera with a tilting tournament, during which the Earl of Essex displays his jealousy while making remarks about the tournament winner Lord Mountjoy with whom he picks a fight - which is interrupted by the arrival of the queen. The scene immediately establishes a dramatic opening for the opera, in that the rivalry between Essex and Mountjoy for the Queen's favour sets the tone for the theme of struggle for the queen's favour, indicating that the opera intends to deal with the internal politics and the balance between different power-blocks during the closing years of the first Elizabethan era.
The focal point in the second act is to further elaborate the contradictions between the Queen's public persona and her personal affection towards the Earl of Essex. The reasons to use English masque as the center piece for the act are, firstly to establish Elizabeth I's dramatic and ritualistic purpose as the head of state; and secondly, to express Britten and Plomer's felicitations for the newly crown queen.

In the opera, the masque takes place at the Guildhall in Norwich and the format Plomer and Britten employ is historically closer to the late medieval or Tudor procession, like the one in Love's Labour's Lost (1596), rather than the much more extravagant and urbanised Stuart masque. In Gloriana, the dramatic function of the procession is to further allegorise the central theme in which the Queen is hailed as the concord of the nation. This theme of ritualized celebration of concord steps away from the details of personal relations to act as a bridge between the first and the second Elizabethan age.

The following two scenes in the second act return to the romantic topic and highlight the Queen's human dimension, portraying her somewhat in the manner of a nineteenthcentury romantic heroine. The Queen's public humiliation of Lady Essex marks a transition from public jubilation in the first scene to a quasi-domestic dispute in the third scene and has the unfortunate effect of blurring the focus of the opera as a civil ritual to celebrate Elizabeth II's coronation.

The third act brings the conclusion of the opera where the Queen is forced to sacrifice her personal affection for the earl in order to fulfill her obligations to her loyal subjects - and maintain her power. In the first scene, the news that Essex has failed to quench the Irish rebellion, coupled with the ambition displayed in his continuous rivalry with other courtiers has put his relationship with the Queen under extreme pressure. As Essex's discontent with the court has escalated into a rebellion, the Queen has no choice but to crush the insurgents and re-assert her authority as the ruling monarch. Even though the act underlines the Queen's supreme regality, the intimate settings in scenes one and three expose her fragility as a romantic heroine.

Plomer's decision to present the Queen in her dressing gown in the presence of Essex has brought a romantic overtone to the piece. And it is this excessive romantic setting, which exposes the dramatic flaw of the piece. The libretto of 
the opera is derived from Lytton Strachey's Elizabeth and Essex; therefore Plomer inherits the writer's idea of treating the relationship between the aging Queen and the young earl as if it were a full-blown romance. However, whatever may have been the emotional tone of their relationship in 1587, by the stage of the opera's setting, an affair between Elizabeth and the Earl of Essex invites derision as not only unrealistic but also historically ungrounded.

\section{CiVIL RITUAL}

As England had turned towards Protestantism during the sixteenth-century, Elizabeth I wisely exploited her country's new religious alignment and presented herself not only as the sacred monarch but also as the virgin queen, in place of the catholic icon of the Virgin Mary [3]. In the second half of the sixteenth-century, the whole of Europe was in a state of religious ferment, which crucially divided the political world of the time. There could be several readings of Elizabeth I's "marriage" to the nation but they all point to a conscious political strategy designed to shore up the position of the Queen.

To this end she employed the term, "marriage" to position herself favourably when the frequent national crises, such as religion, the succession, royal courtships and rumours about her personal conduct caused concern. Furthermore, the queen's partner in this platonic marriage was a sexless nation; thus, this marriage enabled Elizabeth I to switch on or off her physical femininity whenever she required a "kingly" or a "virginal" representation.

Elizabeth I presented herself as the sacred monarch, the head of the Anglican Church; portrayed her image as the Virgin Queen, in recognizable association not only with the Virgin Mary but also, arguably, two of the most popular saints of the time, namely, Uncumber and Frideswide [4]. Her strong association with the catholic saints are a pointed indication of her ambiguous attitudes toward the subject of religion. In public, she was supreme leader of the Church of England which had already broken its ties with the Roman Catholic Church; however in private, she was still attending masses, kept a silver cross in her private chapel and avoided any religious argument, as reported in a letter to Philip II in 1559 by De Feria, one of the Spanish ambassadors.

In the opera, in order to convincingly capture the court atmosphere of the English Renaissance period, the librettist uses the English masque as a medium for the audience to experience the vibrant cultural activities during the first Elizabethan era [5]. This reference has the further advantage for the librettist that it can serve as formal means of signifying the civic jubilation at the coronation of Elizabeth II.

Historical narratives of the kind we have in this opera depend upon a number of standard devices to set the scene and establish period. In this case, to convincingly capture the court atmosphere of the English Renaissance period, the librettist uses the English masque, as a medium for the audience to experience the vibrant cultural activities of that time. As it happens, English masque was fully established only during the reign of King James I; and so it was a hybrid of the Jacobean masque and earlier processio forms which Plomer adapted in the second act of Gloriana [6].

The main purpose of this adaptation of English masque is to re-create the functional element of ritualised public entertainment for the coronation of the new queen. The librettist dramatizes the late Elizabethan courtly ritual for the twentieth-century operatic stage and thus invites the audience to make a legitimate, if slightly wobbly connection between the first and second Elizabethan eras.

Indeed, the masque in Gloriana does highlight a historical moment; six years after the end of the Second World War, Britain was in desperate need of a powerful symbol to reenergize and re-define its national identity and to cast away the daunting years of austerity both during and after the war [7]. Peter Hennessy's study captures the general mood of this period, "it was an age dominated by the shadow of war, its accomplishments and shortcomings constantly measured against the hopes and expectations of 1945, when this time, Britain really was going to be a land fit for returning war heroes to live, work and raise a family in. [...] Britain would remain a great power abroad while operating a mixed economy and building a welfare state at home.” [8] The librettist does go some way to presenting a convincing allegory for the future of the nation by reconstructing the English Renaissance art form and recalling its most successful ruling monarch, Elizabeth I [9]. Both myth and ritual are constantly remoulded to allow for the exploration of human concerns and it sometimes seems that virtually any old myth can be press into service.

\section{ENGLISH MASQUE}

The twentieth-century representation of English masque in Gloriana does preserve the original mode of formal eulogy of the ruling monarch from its early seventeenth-century predecessors; however the differences between the modern revival and its forerunners requires the scene to be fashioned in a slightly modified style [10]. In Gloriana, the main purpose of the inserted masque is to underline the dramatic theme of "time" and "concord", which are presented by male and female performers [11]. Plomer's intention to place "time" and "concord" can be interpreted as the arrival of a new epoch and forecasts a concordant reign under the newly crowned queen [12].

In comparison with Ben Jonson's celebrated masques, Plomer offers a rather blunt approach in reviving this ancient art form. While Jonson's works present an exuberance of images and references from Greek mythology, Plomer's modern revival tends to neglect this particular characteristic in favour of plain allegory. The differences between Jonson's masques and Plomer's revival also reveal the artistic distance between English masques and twentieth century operas [13]. For the early English masques, the key element of a performance was the involvement of every spectator; there was no strict separation between the performers and the audience. The main message, which poets, especially Ben Jonson, intended to convey to the courtiers, was to represent the universal harmony, which was maintained by the virtuous ruling monarch. Thus, in the early English masque, there is no strict sense of stage, especially for the performers; the 
monarch was always the focus of attention throughout the whole piece.

The modern revival, on the other hand, is framed in an operatic format in which the performance is designed not only for the limited numbers of courtiers but also for the general public even though the piece is dedicated to the queen [14]. While there is no division between performers and spectators in English masques, the relationships between performers and audience in an operatic performance can be regarded as less spontaneous. The audience in the twentieth century expects to see a performance rather than to participate in one and is, in any case, unaccustomed to the reading of figurative allegory [15].

This difference in performance practice is reflected in Britten and Plomer's use of the masquers in their collaboration. Even though in Gloriana, the masquers in the second act are not presented as being played by courtiers as in its seventeenth century counterpart but instead by local mummers, the message in the libretto is still echoing their seventeenth century predecessors, where the intention was to honour their ruling monarch through formalised eulogy. The modern version recollects the public's adulation for the character of the queen, Elizabeth I, in order to create an association between the second Elizabethan era and its Renaissance counterpart [16].

Taking Elizabeth I as the subject for the coronation opera is significant: although Elizabeth I's reign was not as entirely serene and was beset by foreign threats, her supremacy, which lasted four and a half decades, did significantly lay down the foundation, not only for the confidence in a future female rule but a strong sense of national identity [17]. The subject builds upon the sense that post-war Britain can be built optimistically in a fresh reign and embracing the fruits of a new epoch [18].

\section{CRITIQUE}

The decision to use English masque as a play within a play in Gloriana also exposes some serious problems in the piece. It is rather obvious that whatever Plomer's intentions, the masque as a dramatic form is simply dead: the audience would be inclined to regard it as an exercise in historical allusion, not as a viable piece of musical theatre. But has been worth some discussion because the masque points to a larger problem in the piece - and that is that the opera does not seem to know where it is going. The purpose of creating Gloriana is to participate in the making of a national myth of cohesion and patriotism for the coronation of Elizabeth II. However, in the mechanics of the plot the audience is given a rather curious blend of "romance" between the aged queen and her clearly unreliable courtier; some historical flummery about the rivalry with Mountjoy; an allegorical masque; and the employment of nineteenth-century myth-making about the Virgin Queen and the creation of English society.

All these historical subplots and mythic elements are cramped and not always relevant in the context of the coronation. The librettist also want to point to the coming of "a new Elizabethan age", but merely gesturing at parallels does not provide any focus on what this may involve and the comparison remains strained. It is true that there tends to be something opaque about myths - part of their power is that they do not have obvious morals or lessons; yet masque is the very antithesis of myth - it is allegorical and allegories are meant to be decoded in a fairly straightforward one-to-one fashion.

Thus, by portraying the ambiguous relationship between Elizabeth I and Robert Devereux, what kind of parallel is being drawn for the new queen? Obviously, being a virgin is not available; what is meant by a "new Elizabethan age"? Shakespeare and Jonsons' works are frequently quoted in the libretto. Does it suggest that the librettist has the intention to match their achievement? Furthermore, how seriously are we meant to take the Essex "romance" aspect? Plomer does not properly decode what it means in such a court to be a "favourite" with the result that the audience finds itself at rather a loss for relevance. In Gloriana, instead of history we get something that slides dangerously towards historical pulp fiction.

Historically, in order to maintain undisputed power, Elizabeth I portrayed herself as a hermaphrodite head of state, thus enabling her to switch on or off her physical femininity as and when it was required. In Gloriana, the librettist discards this politic myth, but also the conventions of courtliness and portrays as if in realistic terms a supposed romantic attachment between the queen and the Earl of Essex and this depiction invites a question about the queen's characterization.

The proposition seems to be that as the sole ruler of the country, the queen has to establish herself as the divinely approved sovereign of her nation. All of her subjects are required to follow her lead and to be "tamed" under her reign. However, as the sovereign of her country, she has to sacrifice her personal feelings to achieve the ultimate submission of her subjects. In order to create a majestic declamation for the queen, the librettist employs words such as, "proud", "break", "pull" and "rule" to indicate vigorous verbal images suggestive of romantic conflict within the queen. But "favourites" at court are normally used to balance contending power-blocs and comparatively rarely as simple sexual objects as Plomer is trying to suggest in the opera. The romantic element in the opera has delivered a confusing signal to the audience which is expecting a more ritualistic and mythic quality in the coronation opera.

The conflict in Elizabeth I's personality is most prominent in her soliloquy at the end of the first act of the opera in which she reflects not only on her mission for the nation but also her private affection for the Earl of Essex. The passage opens with the queen's meditation on the art of maintaining power in a turbulent court. The opening line presents a distinctly Machiavellian image of the ruling monarch as manipulator. However, the queen then suddenly changes her majestic tone as a calculating sovereign to the voice of a love-struck woman. The stage direction "thinking of Essex" is deadly. How is the singer meant to follow this instruction to do a bit of thinking? The libretto has slipped away from the operahouse and into the conventions of the novel. Such a redundant 
stage direction expresses the librettist's hesitation in pinpointing the character's actual motivation.

The following two lines are meant to reveal the queen's strong private attachment to the Earl of Essex, as she reflects, "if life were love [...] then could I love thee through and through!” But is this the relation between monarch and courtier? It is clear that the main theme here is that as the absolute ruler of England, the Queen must refrain from falling into the trap of indulging herself in private emotional adventures. So she is shown as soon composing herself and further affirming as her sole duty, "I live and reign a virgin, / will die in honour, / leave a refulgent crown!” The Queen's private reflection, while undoubtedly noble, brings into question the terms of discussion of her "romantic" attachment to the Earl of Essex; furthermore, it also further imparts a disturbance to the general scheme of the opera as a ritualistic celebration of the newly crowned queen, Elizabeth II.

The decision to use the word, "refulgent", indicates another area of difficulty for the librettist. Historical dramas always present a linguistic problem of representation: it is fatally easy to slip into an artificial and even unintentionally comic tone as one tries to recreate the atmosphere of being in the Elizabethan court. "Refulgent" originated in the early sixteenth-century, first from the Latin word, refulgere which means shining with, or reflecting, a brilliant light. The lustrous impression which the word is intended to convey is meant to reflect the Queen's public image.

Elizabeth I's “The Ditchley Portrait” by Marcus Gheeraerts the Younger, depicts the queen in the most regal, serene and radiant manner. The silvery white gown and her jewellery further elevate her majestic presence and reflect the gleaming sun which lights up the entire canvas. Queen Elizabeth I, therefore, was the refulgent queen. By using such a word, the librettist hopes to creates some aspect of the vivacity of the character through the text and also consciously conjure up the idea of a national myth. Nevertheless, there remains a touch of the "inkhorn" about it. Gloriana, like Gheeraerts' portrait, is created with the intention of capturing its ceremonial purpose and the juxtaposition of Elizabeth I and Elizabeth II in an operatic presentation clearly demonstrates the composer and the librettist's fervent view in re-creating a national myth. The opera is a symbolic gesture to Elizabeth II that she, like Elizabeth I, unites the nation and she will lead the country into a new Elizabethan age. Gloriana also suggests the ritualistic and sacrificial purpose of a ruling monarch. "Refulgent" indeed presents the mythic quality of this coronation opera, though with a lingering sense of trying too hard.

Having grown up in the hostile surroundings of a court full of intrigue, the young Elizabeth had already been forced to learn the art of ambiguity in presentation to ensure her survival; thus nowadays it is virtually impossible to know where exactly she stood in religious matters, as Levin's study reflects, "she was content to believe that God knew what was in her heart, about her faith as in so many other matters, and to let it be.” [19] However, as a Queen, Elizabeth I made a tremendous effort to practice religious ceremonies, such as the
Maundy ceremony and touching for the king's evil, in order to build up a sacred mode of her reign.

In symbolically promoting herself as the sacred monarch, Elizabeth I not only politically strengthened the English identity but also religiously positioned herself as the head of the Anglican Church. For the stability of her country's political environment and religious atmosphere, Elizabeth I therefore created a myth that she sacrificed her private life, in order to embody the ultimate image of a ruling sovereign. Her carefully constructed representation was that as the absolute authority in her court she had brought civil concord to England during the last several decades of the fifteenth century and furthermore that her political determination could even be seen to surpass that of any king. Her image of being a Virgin Mary figure had also successfully spanned the nation's transition from Catholicism to Protestantism.

The queen's virginal personification was also, paradoxically, used to create a tenderly maternal figure as the head of state. However, it was said, her historical achievement was at the cost of her private happiness. In Plomer's libretto, the queen eventually has to sacrifice her private affection for the Earl of Essex in order to affirm her matrimonial bond with her nation [20]. Thus, there is no more appropriate conclusion to the life of Elizabeth I than Plomer's wording for the final scene of the opera, where the queen reflects on her reign, "I have ever used to set the last Judgement Day before mine eyes, and when I have to answer the highest Judge, I mean to plead that never thought was cherished in my heart that tended not to my people's good.”

\section{CONCLUSION}

In a curious climax to an opera, these words are spoken, as if both composer and librettist are fearful that their patriotic message might be lost in the context of musical expression. Plomer refulgently transforms this historical incident into an unusual theatrical format and invites his audience to experience the inner struggle and anguish of a ruling monarch, brought about by the intense personal sacrifice she has to make for the sake of her country. Through Gloriana, Britten and Plomer offer a re-interpretation of the meaning of a sacred monarch, which might span both antiquity and the modern era.

The combination of prose and verse in archaic and modern English in the libretto coupled with Britten's constant mixture of his own style of music with allusions to Tudor melodies, reflects their ambition to re-create a national myth and even to draw a direct association between the first and the forthcoming Elizabethan eras. The fact that the opera is consciously heterogeneous indicates that both the librettist and the composer hoped to connect the Elizabethan style of poetry and music with their twentieth-century audience but lacked the publicly accepted conventional resources which would allow them to signal the ambiguous formalities of courtly love and behaviour.

The fact that the composer and the librettist undertook to participate in several myths about history and the current state of the country does not necessarily diminish their status as myths - nor does it indicate that Britten and Plomer were 
unaware that they were manipulating mythic themes. Whether they succeeded in making these myths live is another question.

\section{REFERENCES}

[1] C. Seymour, The Operas of Benjamin Britten: Expression and Evasion, Woodbridge: The Boydell Press, 2004, pp. 160

[2] E. W. White, Benjamin Britten: His Life and Operas, London: Faber and Faber, 1983, pp. 190-201.

[3] According to Levin's study, "Elizabeth presented herself as a Virgin Queen, echoing the cult not only of the Virg in Mary but also perhaps those of such saints as Frideswide and Uncumber, both of whose shrines had been destroyed in 1538, both of whom were said to be daughters of kings, and both of whose power came from their determined virg inity." See C. Levin, The Heart and Stomach of a King: Elizabeth I and the Politics of Sex and Power, Philadelphia: University of Pennsylvania Press, 1994, pp. 18-19.

[4] C. Levin, The Heart and Sto mach of a King: Elizabeth I and the Politics of Sex and Power, pp. 18-19.

[5] D. Mitchell, "Public and Private in Gloriana” in the Britten Companion ed. by Christopher Palmer, London: Faber and Faber, 1984, pp. 170-176.

[6] J. C. Meagher, Method and Meaning in Jonson's Masques, Notre Dame: University of Notre Dame Press, 1966, pp. 1-30.

[7] B. Hillier, "Introduction" in A Tonic to the Nation: The Festival of Britain 1951, M. Banham and B. Hillier, Eds. London: Thames and Hudson, 1976, pp. 10-19.

[8] C. Seymour, The Operas of Benjamin Britten: Expression and Evasion, p. 160-180. Seymour initiates the essay with the genesis of Britten's Gloriana and further elaborates its parallel elements with the first Elizabethan era.

[9] A. Malloy-Chirgwin, "Gloriana: Britten's 'slighted child”" in The Cambridge Companion to Benjamin Britten, M. Cooke, Eds. pp. 113128.

[10] D. Mitchell, "Public and Private in Gloriana" in the Britten Companion, C. Palmer, Eds. pp. 170-176.
[11] W. Palmer, “Notes on the Libretto of 'Gloriana”" in Opera Guide: Peter Grimes/Gloriana by Britten, N. John, Eds. pp. 99-101.

[12] L. Orrey, Opera: A Concise History, London: Thames and Hudson, 1987, pp. 49-66 and 213-243, in these two chapters, by describing the development of English masque and twentieth century music theatre, the author subtly indicates the contrasting elements in these two genres.

[13] E. W. White, Benjamin Britten: His Life and Operas, London: Faber and Faber, 1983, pp. 59-67; 190-201.

[14] T. Sutcliffe, Believing in Opera, London: Faber and Faber, 1996, pp. 315. The author explores the impact of the contributions bring about by producers who reshape the spectators' opera viewing experiences in the twentieth century.

[15] A. Malloy-Chirgwin, "Gloriana: Britten's 'slighted child”" in The Cambridge Companion to Benjamin Britten, M. Cooke, Eds. pp. 113128.

[16] According to Jeremy Black, "royal fiscal policies, particularly the sale of monopolies to manufacture or sell certain goods, and also additional taxes, led to bitter criticis $\mathrm{m}$ in the Parliaments of 1597 and 1601; and also failed to provide sufficient resources to bring success in war. Puritanism led to disputes in Parliament, especially in 1587 when Puritan MP's tried to legislate for a Presbyterian church settlement, an unsuccessful move that caused an angry dispute between Elizabeth, who opposed changes in relig ious matters, and some MPs. Elizabeth found it difficult to create a stable government after the ministers who had served her for so long - William Cecil, Lord Burghley; Leicester and Walsingham - died.” See J. Black, A History of the British Isles, London: Macmillan, 1997, pp. 110; C. Seymour, The Operas of Benjamin Britten: Expression and Evasion, pp. 160-180.

[17] B. Orr, "Some Reflections on the Operas of Benjamin Britten" in Opera Guide: Peter Grimes/Gloriana by Britten, N. John, Eds. pp.71-74.

[18] R. Hewison, “'Happy were he': Benjamin Britten and the Glo riana story” in Britten's Gloriana: Essays and Sources, P. Banks, Eds. pp. 12-13.

[19] The Heart and Stomach of a King: Elizabeth I and the Politics of Sex and Power, pp. 18.

[20] R. Hewison, “'Happy were he’: Benjamin Britten and the Gloriana story” in Britten’s Gloriana: Essays and Sources, P. Banks, Eds. pp. 12-13. 